\title{
Lactobacilli Are Prominent Members of the Microbiota Involved in the Ruminal Digestion of Barley and Corn
}

OPEN ACCESS

Edited by:

Diego P. Morgavi,

INRA - Centre Auvergne

Rhône-Alpes, France

Reviewed by:

Garret Suen,

University of Wisconsin-Madison,

United States

Eun Joong Kim

Kyungpook National University,

South Korea

Zhongtang Yu,

The Ohio State University,

United States

*Correspondence:

Tim A. McAllister

tim.mcallister@agr.gc.ca

Specialty section:

This article was submitted to Microbial Physiology and Metabolism,

a section of the journal

Frontiers in Microbiology

Received: 26 November 2017

Accepted: 27 March 2018

Published: 10 April 2018

Citation:

Yang HE, Zotti CA, McKinnon JJ and

McAllister TA (2018) Lactobacilli Are

Prominent Members of the Microbiota Involved in the Ruminal Digestion

of Barley and Corn.

Front. Microbiol. 9:718.

doi: 10.3389/fmicb.2018.00718
Hee E. Yang ${ }^{1,2}$, Claiton A. Zotti ${ }^{3}$, John J. McKinnon ${ }^{2}$ and Tim A. McAllister ${ }^{1 *}$

${ }^{1}$ Lethbridge Research and Development Centre, Agriculture and Agri-Food Canada, Lethbridge, AB, Canada, ${ }^{2}$ Department of Animal and Poultry Science, University of Saskatchewan, Saskatoon, SK, Canada, ${ }^{3}$ Department of Animal Science, Universidade do Oeste de Santa Catarina, Xanxerê, Xanxerê, Brazil

The chemical composition of barley grain can vary among barley varieties (Fibar, Xena, McGwire, and Hilose) and result in different digestion efficiencies in the rumen. It is not known if compositional differences in barley can affect the microbiota involved in the ruminal digestion of barley. The objective of this study was to characterize the in situ rumen degradability and microbiota of four barley grain varieties and to compare these to corn. Three ruminally cannulated heifers were fed a low $60 \%$ barley silage, 37\% barley grain, and 3\% supplement) or high grain (37\% barley silage, $60 \%$ barley grain, and 3\% supplement) diet. One set of bags was used to estimate dry matter (DM), starch and crude protein (CP) degradability. A second set was used to extract DNA from the adherent microbiota and visualize grain after incubation using scanning electron microscopy (SEM). DNA was subjected to amplicon 16S rRNA gene sequencing followed by analysis using QIIME. In the low grain diet, McGwire had the highest effective degradability (ED) of DM $(P<0.01)$. The ED of starch was highest $(P<0.01)$ for Fibar, McGwire, and Xena, but the ED of CP was not affected by variety. For the high grain diet, Xena and McGwire had the highest ED of DM $(P<0.01)$. The ED of starch was highest $(P<0.01)$ for Xena and Fibar. The ED of protein was highest $(P<0.01)$ for Xena and McGwire. Although the microbiota did not differ among barley varieties, they did differ from corn and with incubation time. Lactobacilli were dominant members of the mature biofilms associated with corn and barley and were accompanied by a notable increase in the lactic acid utilizing genera, Megasphaera. As none of the cattle exhibited subclinical or clinical acidosis during the study, our results suggest that lactobacilli play a more prominent role in routine starch digestion than presently surmised.

\section{Keywords: barley, corn, rumen, microbiome, starch digestion, cattle, biofilm}

\section{INTRODUCTION}

Barley is ranked as the fourth major cereal crop in the world consumed by humans and livestock (Nikkhah, 2012) and is the primary grain fed to ruminants in Western Canada (Nikkhah, 2012). On average, barley grain is composed of $\approx 60 \%$ starch, $20 \%$ fiber and $12 \%$ protein on a DM basis (Åman and Newman, 1986; Oscarsson et al., 1996). However, the chemical composition, 
nutritive value, and bioavailability of starch can vary among barley varieties due to genetic and environmental factors (Nilan and Ullrich, 1993). Barley grain can be classified as two or six row, hulled or hulless, and on the basis of starch type as normal, waxy (high amylopectin up to 100\%), or high-amylose (amylose up to 70\%) (Kong et al., 1995; Narasimhalu et al., 1995). Variations in the chemical composition and structure of barley grain can affect its ruminal digestibility (Cleary et al., 2011).

Ruminal digestion of barley is dependent on the ability of rumen microbes to colonize and form biofilms on the surface of the grain (McAllister et al., 1994; Beauchemin et al., 2001). Formation of biofilms can be promoted by processing barley grain which enhances microbial attachment and the colonization of starch granules (McAllister et al., 1994). However, even when processed using the same techniques, ruminal digestion can differ among barley varieties. Little is known about how differences in barley grain composition affect the types of rumen bacteria that form biofilms on the surface of barley grain. Previous studies of the microbiota involved in the ruminal digestion of barley grain have primarily relied on culture-based methods and were therefore limited to only those bacteria that could be grown in the laboratory. Recent developments in molecular biology has led to a proliferation in the use of next generation sequencing (NGS) to characterize the ecology of microbial populations in a variety of ecological habitats, including the rumen (Petri et al., 2013). NGS is a culture-free method that enables analysis of the entire bacterial population based on sequencing of the16S rRNA gene. It enables the characterization of the phylogeny and taxonomy of bacteria including those that are associated with complex biofilms. The objectives of this study were (i) to estimate the temporal in situ rumen degradability of four barley grain varieties (Fibar, Xena, McGwire, and Hilose) and (ii) evaluate the temporal formation of bacterial biofilms involved in the digestion of these barley grain varieties. We hypothesized that the population structure of rumen microbial biofilms would differ among barley varieties as a result of differences in their chemical composition. Corn was included in the study as a positive control as it is well known that the chemical composition of corn differs dramatically from barley (Peter and Herbert, 2013) and grain colonization was investigated using heifers fed both low and high grain diets.

\section{MATERIALS AND METHODS}

\section{Animal and Diets}

Three rumen-cannulated heifers (BW: $308 \mathrm{~kg} \pm 32 \mathrm{SD}$ ) were individually housed for the duration of the experiment with free access to clean drinking water. The heifers were fed ad libitum twice daily at 08:00 and 16:00 h. The study was reviewed and approved by the Lethbridge Research Centre Animal Care Committee and conducted according to the guidelines of the Canadian Council on Animal Care [CCAC] (2009). In the first experiment, heifers were adapted to a low grain diet (DM basis) consisting of $60 \%$ barley silage, $37 \%$ steam rolled barley and $3 \%$ of a standard feedlot supplement for a period of 21 days
(Table 1). In situ incubations were conducted and then heifers were adapted to a high grain diet over 14 days. In the second experiment, the diet consisted of $37 \%$ barley silage, $60 \%$ steam rolled barley and 3\% supplement (Table 1). Heifers were fed the second diet for an additional 14 days prior to in situ incubations.

\section{Incubation of Barley Varieties and Corn in the Rumen}

Prior to placement in nylon bags, barley varieties (Fibar, Xena, McGwire, and Hilose) and corn were ground using a Wiley mill (Arthur H. Thomas Co.) fitted with a $6 \mathrm{~mm}$ screen. A $6 \mathrm{~mm}$ screen was selected to ensure that both compositional and structural traits of the grain influenced biofilm formation on the grain surface. It also facilitated the collection of grain particles for examination using scanning electron microscopy (SEM). In situ dry matter (DM), starch and crude protein (CP) disappearance were estimated using three heifers. Samples were hot weighted ( $3 \mathrm{~g}$ ) into $50 \mu \mathrm{m}$ pore size (\#R510) Dacron nylon bags $(5 \mathrm{~cm} \times 10 \mathrm{~cm}$; Ankon, Fairport, NY, United States), that were placed in a larger mesh bag and removed from the rumen after $0,2,4,12,24$, and $48 \mathrm{~h}$. The same nylon bags containing grains (5 g) for DNA extraction and SEM were incubated in two of the heifers and removed from the rumen after 2, 4, and $12 \mathrm{~h}$. Bags used to estimate in situ disappearance were retrieved from the rumen and thoroughly rinsed with cold tap water until the water was clear. Bags were then washed in a washing machine for $2 \mathrm{~min}$ without the spin cycle, prior to being dried at $55^{\circ} \mathrm{C}$ for $48 \mathrm{~h}$. For DNA extraction, samples were rinsed with phosphate buffer three times to remove non-adherent bacteria and contents were flash-frozen in liquid nitrogen. For SEM, two or three random particles from the bags were placed into a prefix solution containing $0.5 \%$ glutaraldehyde, $0.15 \%$ ruthenium red in $0.2 \mathrm{M}$ phosphate buffer saline at a $\mathrm{pH}$ of 7.2. Zero hour bags were not placed in the rumen, but were washed in the same manner as the other bags.

TABLE 1 | Diet composition.

\begin{tabular}{lcc}
\hline Composition & Low concentrate & High concentrate \\
\hline Ingredients (\% of dry matter) & 60 & 37 \\
Barley silage & 37 & 60 \\
Barley grain & 3 & 3 \\
Supplement ${ }^{2}$ & & \\
Composition (\% of dry matter & 12.0 & 12.1 \\
Crude protein & 24.9 & 11.8 \\
Acid detergent fiber & 36.2 & 19.7 \\
Neutral detergent fiber & 16.7 & 35.2 \\
Starch &
\end{tabular}

aThe supplement contained canola meal (10\%), urea (2\%), calcium carb (25\%), sodium chloride (3\%), ground barley grain (56.5\%), molasses (2.5\%) and feed lot premix (1\%). The premix contained calcium carbonate (34.8\%), zinc sulfate (28.4\%), manganous sulfate (14.6\%), copper sulfate (10.3\%), ethylene diaminediiodic acid $(0.2 \%$; as an $80 \%$ preparation), selenium (5\%), cobalt sulfate $(0.1 \%)$, vitamin $A$ $\left(1,000,000 \cup \mathrm{g}^{-1} ; 1.7 \%\right)$, vitamin $\mathrm{D}\left(500,000 \mathrm{U} \mathrm{g}^{-1} ; 0.2 \%\right)$ and vitamin $E(4.7 \%)$. 


\section{DNA Extraction of Bacterial Biofilms}

Samples for DNA extraction $(n=3)$ were freeze-dried and $2-4 \mathrm{~g}$ were ground for $5 \mathrm{~min}$ at a frequency of 30 cycles/s using a Qiagen TissueLyser II (Qiagen, Toronto, ON, United States). DNA was extracted using a Qiagen QIAamp DNA stool mini kit with minor modifications. Briefly, $300 \mathrm{mg}$ of ground substrate were placed into a $2 \mathrm{ml}$ micro centrifuge tube along with $1.4 \mathrm{ml}$ of ASL buffer (cell lysis) and the mixture was vortexed for $1 \mathrm{~min}$. Glass beads (200 mg with $0.5 \mathrm{~mm}$ diameter and $300 \mathrm{mg}$ with $1.0 \mathrm{~mm}$ diameter) were added to each tube and the samples were processed in a bead-beating homogenizer (B. Braun, Melsungen AG, Germany) for $3 \mathrm{~min}$ at maximum amplitude. The tubes were then centrifuged $(13,000 \times g, 5 \mathrm{~min})$ and subsequently extracted following the QIAamp DNA stool mini kit instructions. After extraction, DNA was quantified using a NanoDrop 3300 (Thermo, Waltham, MA, United States).

\section{Pyrosequencing of the 16S rRNA Gene}

Extracted DNA was analyzed using bacterial tag-encoded FLX 16s rRNA amplicon pyrosequencings (bTEFAP). The 16S rRNA gene universal bacterial primers 27F-519R (27F 5'-AGRGTTTGATCMTGGCTCAG, 519R 5'GTNTTACNGCGGCKGCTG), were used to amplify the hypervariable regions $\mathrm{V} 1$ to $\mathrm{V} 3$ of the $16 \mathrm{~S}$ rRNA gene as described by Dowd et al. (2008). All DNA samples were adjusted to100 $\mathrm{ng} / \mu \mathrm{l}$ and an $1 \mu \mathrm{l}$ aliquot (100 $\mathrm{ng}$ ) of each sample of extracted DNA was used in a $50 \mu \mathrm{l}$ PCR reaction. Reactions were performed using a HotStarTaq plus Master Mix Kit (Qiagen, Valencia, CA, United States) with the following conditions: $94^{\circ} \mathrm{C}$ for $3 \mathrm{~min}$, followed by 28 cycles of $94^{\circ} \mathrm{C}$ for $30 \mathrm{~s} ; 53^{\circ} \mathrm{C}$ for $40 \mathrm{~s}$; and $72^{\circ} \mathrm{C}$ for $1 \mathrm{~min}$; followed by a final elongation step at $72^{\circ} \mathrm{C}$ for $5 \mathrm{~min}$. Following PCR, all amplicon products from different samples were mixed in equal concentrations and purified using Agencourt Ampure beads (Agencourt Bioscience Corporation, Beverly, MA, United States). Prepared libraries were sequenced utilizing Roche 454 FLX titanium (454 Life Sciences, a Roche company, Branford, CT, United States) technology with reagents and execution of the procedure as per manufacturer's guidelines. Sequence data was submitted to short read database of NCBI and awarded accession SRP132480.

\section{Sequencing Analysis by QIIME 1.9.1}

$16 \mathrm{~S}$ rRNA gene sequences were processed and analyzed with the QIIME software package v. 1.9.1 (Caporaso et al., 2010). All samples were demultiplexed and sequences were quality filtered for, low quality or ambiguous reads and homopolymers and sequences with an average Phred score of $<25$ were removed. Chimeric sequences were removed using the UCHIME algorithm implemented in USEARCH (version 6.1544). The remaining high quality $16 \mathrm{~S}$ rRNA gene sequences were clustered into OTUs (operational taxonomic units) at $97 \%$ similarity using the de novo reference OTU picking method and USEARCH (version 6.1544). Taxonomy was assigned using the UCLUST consensus taxonomy assigner (Edgar, 2010). PyNAST (Caporaso et al., 2010) was used to align the representative sequences for each OTU and a phylogenetic tree was created using FastTree (Price et al., 2010).

\section{Chemical Analysis of Barley Grain Varieties and Corn}

Briefly, lipids were determined using the Goldfisch extraction apparatus (Labconco Corporation, Kansas, MO, United States) with petroleum ether as the solvent (AOAC, 2010). Total nitrogen (TN) was measured by combustion analysis using a Leco Carbon/Nitrogen analyzer (TruSpec CN, Leco Corporation, St. Joseph, MI, United States), with CP calculated as TN $\times 6.2$. Soluble dietary fiber (SDF) and insoluble dietary fiber (IDF) were quantified using the enzymatic gravimetric procedures of AOAC Methods 993.19 and 991.42, respectively (AOAC, 1997) using Megazyme's total dietary fiber assay kit (Megazyme International Ireland Ltd., Wicklow, Ireland). Total dietary fiber (TDF) was calculated as SDF plus IDF. Contents of starch and $\beta$-glucan were estimated according to the total starch (AA/AMG) and the mixed-linkage $\beta$-glucan assays, respectively (Megazyme International Ltd., Bray, Ireland). Amylose content of starch was determined using the iodine blue method as defined by the Corn Refiners Association (1997). Starch content of the grain residues remaining after ruminal incubation was determined by hydrolyzing starch to glucose polymers using amyloglucosidase (Megazyme International Ltd.) plus 1,4- $\alpha$-d-glucan glucanohydrolase (Brenntag Canada Inc., Toronto, ON, Canada) as described by Herrera-Saldana et al. (1990). For measurement of starch, samples were ground using a ball mill (Mixer Mill MM 2000, Retsch, Germany) to a fine powder. Samples (0.1 g) were weighed into $50-\mathrm{ml}$ test tubes and $25 \mathrm{ml}$ of $0.1 \mathrm{~N} \mathrm{Na}$-acetate buffer ( $\left.\mathrm{pH} 5.0, \mathrm{Ca}^{2+} 70 \mathrm{ppm}\right)$ was added. Amylase $(200 \mu \mathrm{l}$; Termamyl, Novo Nordisk, Bagsvaerd, Denmark) was added and tubes were vortexed immediately and subsequently at 15-min intervals. For starch determination, tubes were incubated in a water bath $\left(98^{\circ} \mathrm{C}\right)$ for $1 \mathrm{~h}$ to gelatinize and hydrolyze starch. Activated carbon (approximately 0.04 g; Darco_G-60 Activated Carbon, Fisher Scientific Co., No D-127) was added to the tubes, which were then placed for $15 \mathrm{~min}$ in a $60^{\circ} \mathrm{C}$ waterbath and amyloglucosidase $(500 \mu \mathrm{L}$, Boehringer Mannheim, Laval, QC, Canada, no. 208-469) was added. Samples were centrifuged $(695 \times g$ for $10 \mathrm{~min})$ and $500 \mu \mathrm{l}$ of supernatant was diluted with $9.5 \mathrm{ml}$ of distilled water, and $50 \mu \mathrm{l}$ was transferred to a micro plate. Glucose trinder reagent was added (150 $\mu$ l, Sigma Chemical Co. No. 315-100), and released glucose was determined colorimetrically at $490 \mathrm{~nm}$ using a plate reader.

\section{Scanning Electron Microscopy (SEM)}

Residues of barley grain and corn were fixed in a pre-fix solution $(0.5 \%$ glutaraldehyde and $0.15 \%$ ruthenium red in $0.2 \mathrm{M}$ phosphate buffer, $\mathrm{pH}$ 7.2). After $2 \mathrm{~h}$, feed particles were removed from the pre-fix solution, and a fix solution of $5 \%$ glutaraldehyde and $0.05 \%$ ruthenium red in $0.2 \mathrm{M}$ phosphate buffer ( $\mathrm{pH} 7.2$ ) was added so as to cover the sample. The fix solution was removed after $2 \mathrm{~h}$ and a wash solution (0.2M phosphate buffer and $0.05 \%$ ruthenium red, $\mathrm{pH} 7.2$ ) was added and incubated for $20 \mathrm{~min}$. The wash step was repeated two more times, the final wash solution was removed and a post-fix solution was added $\left(2 \% \mathrm{OsO}_{4}\right.$ and $0.05 \%$ ruthenium red in $0.2 \mathrm{M}$ phosphate buffer, $\mathrm{pH} 7.2$ ). The sample was gently shaken for $2 \mathrm{~h}$ and washed five times with 
wash solution at $10 \mathrm{~min}$ intervals. Samples were then dehydrated using a graduate ethanol series containing 10\%, 20\%, 30\% 50\%, $70 \%, 95 \%$, and $100 \%$, ethanol with samples allowed to stand for $15 \mathrm{~min}$ at each increment. The specimens were mounted on aluminum stubs with silver paste, coated with gold and observed using a Hitachi S-570 scanning electron microscope (Hitachi High Technologies, Tokyo, Japan) at an accelerating voltage of 19 $\mathrm{kV}$ and were photographed with images digitally captured using Quartz PCI software (Quartz Imaging Corporation, Vancouver, BC, Canada).

\section{In Situ Degradability of Four Barley Varieties and Corn}

In situ DM disappearance of each grain type was determined gravimetrically as the difference between initial and remaining weight of DM after ruminal incubation at each time point. Kinetic parameters of DM, starch, and protein were calculated using the equation (McDonald, 1981):

$$
D=a+b\left(1-e^{-c(t-l a g)}\right) \text { for } t>\text { lag }
$$

Where $\mathrm{D}=$ ruminal disappearance at time $\mathrm{t}, \mathrm{a}=$ the rapidly degradable fraction, $\mathrm{b}=$ the slowly degradable fraction, $\mathrm{c}=$ the rate at which $\mathrm{b}$ was degraded $(/ \mathrm{h}), \mathrm{t}=$ time of incubation $(\mathrm{h})$, and lag = lag time (h). The parameters a, b, c and lag were estimated using NLIN procedure of SAS (SAS 9.3, SAS Institute Inc., Cary, NC, United States). Effective degradability (ED) of DM, starch, and protein were estimated using the equation of Ørskov and McDonald (1979), ED = a $+\mathrm{bc} /(\mathrm{c}+\mathrm{k})$, where $\mathrm{k}$ was the ruminal passage rate of $0.06 / \mathrm{h}$.

All data for each grain type associated with each diet were analyzed as a completely randomized design using PROC MIXED procedure of SAS. For the in situ study, the mixed model included the fixed effects of grain type and the random effects of heifer and sample. Replicates within heifer were averaged prior to statistical analysis. Results from the two diet types were analyzed separately as the studies were conducted at different times. Effects of fixed factors were tested using LSMEANS with the PDIFF in SAS and significance was declared at $P<0.05$. Trends were discussed at $0.05<P<0.10$ unless otherwise stated.

\section{Rumen Particle-Associated Bacteria Sequencing Analysis}

Bacterial diversity within each sample (alpha-diversity) was calculated within QIIME using the Chaol estimator (Chao, 1984), observed species (observed OTUs), Shannon's diversity index (Shannon, 1948), PD whole tree [phylogenetic diversity (PD) whole tree] (Faith, 1992), and Goods coverage (Good, 1953) metrics. The bacterial community structure (beta-diversity) within biofilms from all four barley varieties and corn was evaluated using the unweighted and weighted UniFrac distances (Lozupone and Knight, 2005) and visualized as principal coordinate analysis (PCoA) plots using Emperor (VazquezBaeza et al., 2013). ANOSIM (analysis of similarities) with 999 permutations was used to compare the unweighted UniFrac distances.
Linear discriminant analysis effect size (LefSe) was used to determine which taxa group differed according to incubation time of corn and barley in heifers fed the low and high grain diet. LefSe includes the Kruskal-Wallis test to identify significantly different $(P<0.05)$ taxa among groups of samples followed by linear discriminant analysis which estimates the effect size of each of these differences (Segata et al., 2011).

\section{RESULTS}

\section{Chemical Composition of Barley Varieties and Corn}

For this study, four barley grain varieties (Fibar, Xena, McGwire, and Hilose) of differing composition and corn were used (Table 2). McGwire and Xena were normal starch varieties (approximately $12 \%$ amylose and $88 \%$ amylopectin); Fibar, was a waxy type with high $\beta$-glucan, protein, SDF and, TDF content, but low starch content. Hilose was a high-amylose type with 63\% of the starch composed of amylose. Corn, was higher in starch, fat, and IDF than barley, but lower in $\beta$-glucan, protein, SDF, and TDF.

\section{Ruminal in Situ Degradability of Different Barley Varieties in Heifers Fed Low or High Grain Diets}

With the low grain diet, the rapid (A) and slow degradable (B) fractions, degradation rate $(\mathrm{Kd})$, the potential degradable fraction $(\mathrm{A}+\mathrm{B})$ and $\mathrm{ED}$ of $\mathrm{DM}$ differed $(P<0.01)$ among grain types (Table 3 ). For DM, the A fraction was the highest $(P<0.01)$ for corn (Table 3 and Figure 1A) and the lowest for Fibar. The fraction $\mathrm{B}$ of $\mathrm{DM}$ was the highest $(P<0.01)$ for Hilose and lowest for Xena. Degradation rate $(\mathrm{Kd})$ of $\mathrm{DM}$ was the fastest $(P<0.01)$ for Xena and slowest for Corn. The potential degradability fraction $(A+B)$ of $D M$ ranked as Hilose $>$ Corn $>$ McGwire $>$ Fibar $>$ Xena. The highest ED values $(P<0.01)$ were observed with $\mathrm{McGwire}$ and the lowest with Corn. For starch, the rapidly degradable fraction (A) was highest for Fibar $(P<0.01$; Table 3 and Figure 1C). Hilose had the highest slowly degradable fraction (B). The Kd of starch was fastest for Xena and Fibar. The ED of starch was highest $(P<0.01)$ for Fibar and Xena, and lowest $(P<0.01)$ for Corn. For protein, the rapidly degradable fraction (A) was highest $(P<0.01)$ for Corn and lowest $(P<0.01)$ for Fibar (Table 3 and Figure 1E). The slowly degradable fraction (B) was highest $(P<0.01)$ for Fibar and lowest for Corn. The Kd of protein was fastest for Fibar and lowest for Corn. However, the ED of protein did not differ among grain types.

When heifers were fed the high grain diet, the rapidly degradable DM fraction $(\mathrm{A})$ was highest $(P<0.01)$ for Corn (Table 3 and Figure 1B) and lowest for Fibar. The Kd of DM was fastest $(P<0.01)$ for Xena and lowest for Corn. The potential degradable DM fraction $(\mathrm{A}+\mathrm{B})(P<0.01)$ ranked as Corn $=$ Fibar $=$ Hilose $=$ McGwire $>$ Xena, but Xena and McGwire had a higher ED $(P<0.01)$ than Hilose and Corn. The rapidly degradable fraction $(A)$ of starch was highest 
TABLE 2 | Chemical composition of four different barley grain varieties and corn (values represent mean percentage with standard deviation from triplicate measurements (\% of dry matter).

\begin{tabular}{|c|c|c|c|c|c|c|c|c|}
\hline \multirow[b]{2}{*}{ Grain types } & \multirow[b]{2}{*}{$\mathbf{B G}^{\mathbf{a}}$} & \multirow[b]{2}{*}{ Starch } & \multirow[b]{2}{*}{ Amylose } & \multirow[b]{2}{*}{ Protein } & \multirow[b]{2}{*}{ Fat } & \multicolumn{3}{|c|}{ Dietary fiber } \\
\hline & & & & & & SDF $^{b}$ & IDF $^{c}$ & TDF $^{\mathrm{d}}$ \\
\hline Fibar & $10.1 \pm 0.12$ & $47.8 \pm 0.08$ & $0.2 \pm 0.01$ & $15.6 \pm 0.06$ & $2.6 \pm 0.04$ & $7.9 \pm 0.17$ & $11.0 \pm 0.24$ & $18.9 \pm 0.21$ \\
\hline McGwire & $4.6 \pm 0.07$ & $52.5 \pm 0.18$ & $11.5 \pm 0.88$ & $12.7 \pm 0.01$ & $2.0 \pm 0.05$ & $5.6 \pm 0.38$ & $8.6 \pm 0.21$ & $14.2 \pm 0.58$ \\
\hline Hilose & $6.6 \pm 0.14$ & $49.0 \pm 0.03$ & $18.0 \pm 0.25$ & $12.6 \pm 0.08$ & $3.0 \pm 0.14$ & $7.4 \pm 0.31$ & $9.5 \pm 0.20$ & $16.9 \pm 0.51$ \\
\hline Xena & $4.1 \pm 0.16$ & $56.1 \pm 0.15$ & $11.2 \pm 0.28$ & $11.4 \pm 0.05$ & $1.6 \pm 0.05$ & $5.1 \pm 0.41$ & $10.4 \pm 0.54$ & $15.5 \pm 0.15$ \\
\hline Corn & $0.31 \pm 0.00$ & $62.2 \pm 0.44$ & $17.1 \pm 0.74$ & $7.9 \pm 0.03$ & $3.95 \pm 0.1$ & $1.14 \pm 0.10$ & $12.2 \pm 0.25$ & $13.3 \pm 0.14$ \\
\hline
\end{tabular}

${ }^{a} B G,{ }^{b} S D F,{ }^{c} I D F$, and ${ }^{d} T D F$ represent $\beta$-glucan, soluble dietary fiber, insoluble dietary fiber and total dietary fiber, respectively.

for Fibar $(P<0.01$; Table 3 and Figure 1D). Xena had the highest $\mathrm{Kd}$ and $\mathrm{ED}$ of starch. The ED of protein was ranked as Xena $=$ McGwire $>$ Corn $>$ Hilose $>$ Fibar $($ Table 3 and Figure 1F).

\section{Differences in Particle-Associated Bacteria (PAB) Among Corn and the Four Barley Varieties in Heifers Fed a Low Grain Diet}

A total of 604,714 raw sequences were generated from the corn and four barley varieties collected from heifers fed the low grain diet. After trimming, quality filtering and chimera removal, a total of 464,120 sequences remained, with an average length of 421 bp. With a cut-off of $97 \%$ sequence similarity, 945 bacterial OTUs were obtained. The 945 OTUs were classified into 10 phyla, 29 families, 51 genera, and 1 unclassified group. For grain associated biofilms, species richness, $\mathrm{PD}$, observed species and evenness were assessed using, Chao1, a PD whole tree, observed OTUs, and Shannon's diversity index, respectively (Figure 2A). Good's coverage illustrated similar sequence coverage among grain samples (Supplementary Figure 1A). We found no difference in observed species or Shannon diversity among corn and barley varieties. However, there was a tendency for Choal $(P=0.06)$ and PD $(P=0.08)$ to differ between corn and barley varieties.

Bacterial communities did not differ among barley varieties (Figure 3A), but interestingly, the bacterial communities associated with corn and barley grains at $12 \mathrm{~h}$ of incubation tended to separate from those at 2 and $4 \mathrm{~h}$ (Figure 3B). Animal variation was observed at 2 and $4 \mathrm{~h}$. Despite this, the microbiota became less dissimilar by $12 \mathrm{~h}$ showing that initial differences by animal were reduced as fermentation progressed (Figure 3C).

Although the bacterial communities did not differ among barley varieties, there were noticeable differences in the bacterial communities during the incubation (Figure 4). At $2 \mathrm{~h}, 15$ genera were noticeably higher in the biofilm associated with barley grain as compared to biofilms after 4 and $12 \mathrm{~h}$ of incubation. After $4 \mathrm{~h}$ of incubation, Sharpea, Coprococcus, and Ruminobacter were higher in biofilms associated with barley grain than after 2 and $12 \mathrm{~h}$. After $12 \mathrm{~h}$ of incubation, Lactobacillus and Megasphaera were more abundant in the biofilm than at 2 and $4 \mathrm{~h}$. In addition, Figure 5 shows that the increase in lactic acid-utilizing bacteria (Megasphaera; Figure $\mathbf{5 A}$ and
Selenomonas; Figure 5B) correlated with changes in lactic acid producing bacteria (Lactobacillus; Figure 5C). Lactobacillus was positively correlated ( $r=0.76)$ with Megasphaera and negatively correlated $(r=-0.80)$ with Selenomonas. This highlights the relationship between lactic acid producers and utilizers and the use of lactate as a substrate in the rumen. Prevotella was the most dominant genus accounting for $16.5,6.1,10.8,6.3$, and $7.8 \%$ in corn, Fibar, Xena, Hilose, and McGwire, respectively, after $2 \mathrm{~h}$ of incubation (Figure 6A). After $4 \mathrm{~h}$ of incubation, Prevotella (16.3\%) predominanted, followed by unclassified Succinivibrionaceae, unclassified Lachnospiraceae, and Sharpea in corn. In contrast, Sharpea was the most abundant in Fibar, Hilose, McGwire, and Xena, representing 17.3, 16.8, 17.9, and 19.1\% of the population, respectively (Figure 6B). After $12 \mathrm{~h}$ of incubation, Lactobacillus was the most abundant in both corn and barley (Figure 6C).

The comparison of corn and barley grain showed that three genera including an unclassified Succinivibrionaceae, Ruminobacter, and an unclassified Ruminococcaceae significantly increased in corn than barley grain after $2 \mathrm{~h}$ of incubation (Figure 7A). At this time, four genera (Succiniclasticum, unclassified SR1, unclassified Paraprevotellaceae, and unclassified Lachnospiraceae) were higher $(P<0.05)$ in corn than barley, whereas Lactobacillus and Sharpea were higher in barley than corn (Figure 7B). Moreover, at $12 \mathrm{~h}$ incubation, unclassified Lachnospiraceae, Prevotella, unclassified Clostridiales, Selenomonas, unclassified Succinivibrionaceae, unclassified SR1, YRC22, unclassified YS2, and Anaerovibrio were higher $(P<0.05)$ in corn than in barley varieties (Figure 7C).

\section{Differences in Particle-Associated Bacteria (PAB) Among Corn and the Four Barley Varieties in Heifers Fed a High Grain Diet}

With the high grain diet, a total of 395,972 raw sequences were generated. After trimming, quality filtering and chimera checking, a total of 156,814 sequences remained; with an average length of $400 \mathrm{bp}$. The reads were clustered into 815 OTUs, and their representative sequences were used in taxonomic analysis. The 815 OTUs were classified into 7 phyla, 29 families, 53 genera and 1 unclassified group. Species diversity, richness and evenness were calculated as described above. No significant differences in Chaol (species richness), observed species (observed OTUs), 
TABLE 3 | In situ degradability estimates of a corn and four barley varieties in heifers fed either a low or high grain diet.

\begin{tabular}{|c|c|c|c|c|c|c|}
\hline Low grain diet & Corn & Fibar & Hilose & McGwire & Xena & SEM \\
\hline A (\%) & $18.16^{\mathrm{a}}$ & $11.33^{\mathrm{C}}$ & $13.19^{b}$ & $12.47^{\mathrm{bc}}$ & $12.26^{\mathrm{bc}}$ & 0.35 \\
\hline B (\%) & $75.66^{\mathrm{bc}}$ & $79.60^{\mathrm{ab}}$ & $81.63^{a}$ & $78.22^{\mathrm{abc}}$ & $73.29^{\mathrm{C}}$ & 1.34 \\
\hline $\mathrm{Kd}(/ \mathrm{h})$ & $0.04^{d}$ & $0.12^{\mathrm{b}}$ & $0.07^{c}$ & $0.14^{\mathrm{a}}$ & $0.15^{a}$ & 0.00 \\
\hline $\mathrm{A}+\mathrm{B}(\%)$ & $93.82^{\mathrm{a}}$ & $91.00^{\mathrm{ab}}$ & $94.81^{\mathrm{a}}$ & $90.69^{\mathrm{ab}}$ & $85.55^{b}$ & 1.37 \\
\hline \multicolumn{7}{|c|}{ Starch } \\
\hline A (\%) & $12.50^{\mathrm{b}}$ & $22.54^{\mathrm{a}}$ & $7.00^{b}$ & $12.04^{b}$ & $10.04^{\mathrm{b}}$ & 1.09 \\
\hline B (\%) & $85.31^{\mathrm{ab}}$ & $73.42^{b}$ & $91.43^{\mathrm{a}}$ & $84.87^{\mathrm{ab}}$ & $87.52^{\mathrm{ab}}$ & 1.25 \\
\hline $\mathrm{Kd}(/ \mathrm{h})$ & $0.03^{d}$ & $0.12^{\mathrm{a}}$ & $0.07^{c}$ & $0.10^{\mathrm{b}}$ & $0.14^{\mathrm{a}}$ & 0.00 \\
\hline ED (6\%/h) & $43.70^{\mathrm{C}}$ & $70.83^{a}$ & $55.48^{b}$ & $65.58^{a}$ & $70.69^{a}$ & 0.68 \\
\hline \multicolumn{7}{|c|}{ Protein } \\
\hline $\mathrm{Kd}(/ \mathrm{h})$ & $0.03^{c}$ & $0.14^{a}$ & $0.06^{\mathrm{ab}}$ & $0.10^{\mathrm{a}}$ & $0.11^{\mathrm{a}}$ & 0.01 \\
\hline ED (6\%/h) & 82.76 & 84.21 & 80.74 & 83.90 & 85.38 & 1.49 \\
\hline High grain diet & Corn & Fibar & Hilose & McGwire & Xena & SEM \\
\hline \multicolumn{7}{|c|}{ Dry matter } \\
\hline A (\%) & $20.17^{a}$ & $11.82^{d}$ & $14.74^{b}$ & $13.29^{c}$ & $13.29^{c}$ & 0.35 \\
\hline B (\%) & 68.82 & 73.08 & 70.19 & 72.24 & 67.37 & 1.59 \\
\hline $\mathrm{Kd}(/ \mathrm{h})$ & $0.04^{d}$ & $0.10^{\mathrm{bc}}$ & $0.08^{c}$ & $0.13^{\mathrm{ab}}$ & $0.14^{a}$ & 0.01 \\
\hline A+B (\%) & $88.99^{a}$ & $84.90^{\mathrm{ab}}$ & $84.92^{\mathrm{ab}}$ & $85.53^{\mathrm{ab}}$ & $80.66^{b}$ & 1.59 \\
\hline ED (6\%/h) & $44.64^{c}$ & $56.61^{\mathrm{ab}}$ & $52.65^{\mathrm{b}}$ & $59.05^{a}$ & $60.12^{a}$ & 1.45 \\
\hline \multicolumn{7}{|c|}{ Protein } \\
\hline A (\%) & $76.47^{a}$ & $50.70^{d}$ & $62.94^{c}$ & $62.36^{c}$ & $66.42^{b}$ & 0.42 \\
\hline B (\%) & $23.53^{d}$ & $44.62^{\mathrm{a}}$ & $35.92^{b}$ & $34.89^{b}$ & $30.06^{c}$ & 0.45 \\
\hline $\mathrm{Kd}(/ \mathrm{h})$ & $0.03^{c}$ & $0.13^{\mathrm{a}}$ & $0.07^{b}$ & $0.13^{\mathrm{a}}$ & $0.12^{\mathrm{ab}}$ & 0.00 \\
\hline ED (6\%/h) & $84.47^{b}$ & $80.86^{d}$ & $82.13^{\mathrm{c}}$ & $86.26^{a}$ & $86.42^{\mathrm{a}}$ & 0.19 \\
\hline
\end{tabular}

a,b,ab,c,d,e Means in the same row with different superscripts differ $(P<0.01) . A=$ the fast degradable fraction; $B=$ the slowly degradable fraction; $K d=$ degradation rate; $A+B=$ the potential degradable fraction; $E D=$ effective degradability of dry matter, starch and protein; 1/effective degradability in the rumen (assuming rate of passage of $0.06 / h^{-1}$ ); ED = effective degradability of dry matter; 1/effective degradability in the rumen (assuming rate of passage of $0.06 / h^{-1}$ ).

PD whole tree, or Shannon's diversity index were observed among corn and the four barley varieties (Figure 2B). Good's coverage was also similar among grain types (Supplementary Figure 1B). Our results showed that the PCoA in heifers fed the high grain diet produced results that were similar to that observed when the heifers were fed a low grain diet. Bacterial communities clustered more by individual heifer at early incubation times ( 2 and $4 \mathrm{~h}$ ), but after $12 \mathrm{~h}$ biofilms had matured and were similar between animals. In heifers fed the high grain diet, Prevotella, unclassified Succinivibrionaceae, and unclassified Ruminococcaceae were higher $(P<0.05)$ in barley grain after $2 \mathrm{~h}$ than after 4 and $12 \mathrm{~h}$ of incubation, and Lactobacillus was higher $(P<0.05)$ at $12 \mathrm{~h}$ than at the other incubation times (data not shown).

A total of 53 genera were identified across all samples, with the fifteen most abundant genera displayed in Figure 8. After 2 and $4 \mathrm{~h}$ of incubation, Prevotella was most abundant in corn and barley grains, followed by unclassified Veillonellaceae (Figures 8A,B). Whereas after $12 \mathrm{~h}$ of incubation, Lactobacillus was higher in corn (44.5\%), Fibar (57.0\%), Xena (45.0\%), Hilose 
A

Heifers fed a low grain diet
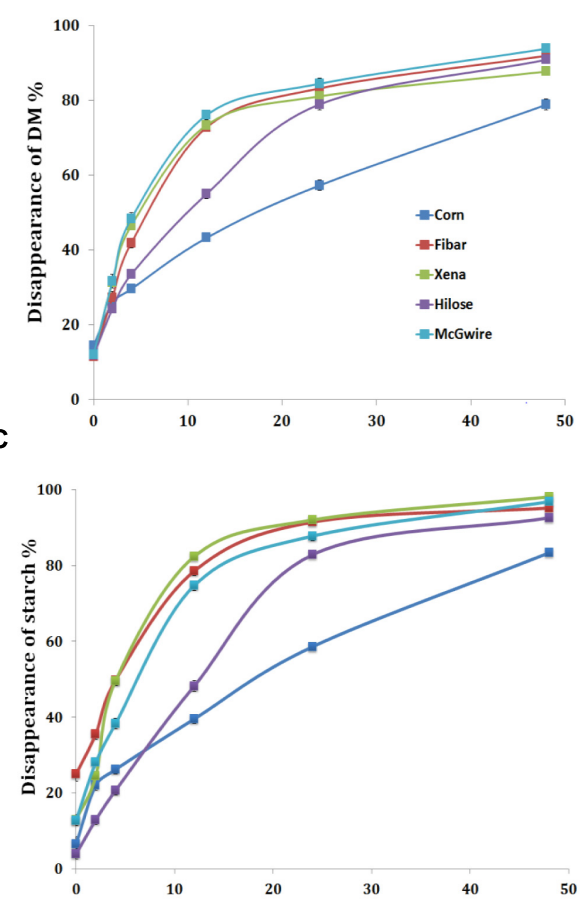

E

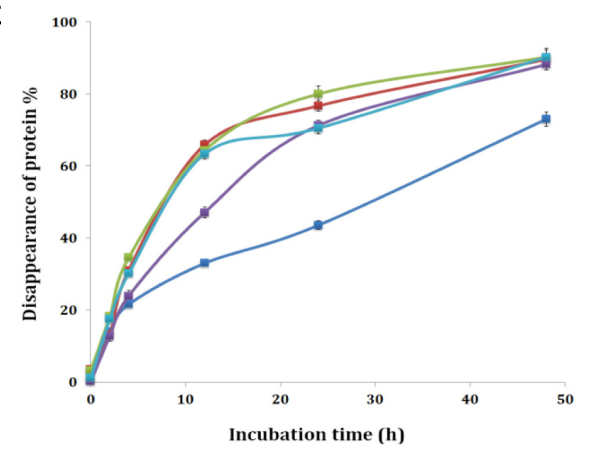

B

Heifers fed a high grain diet
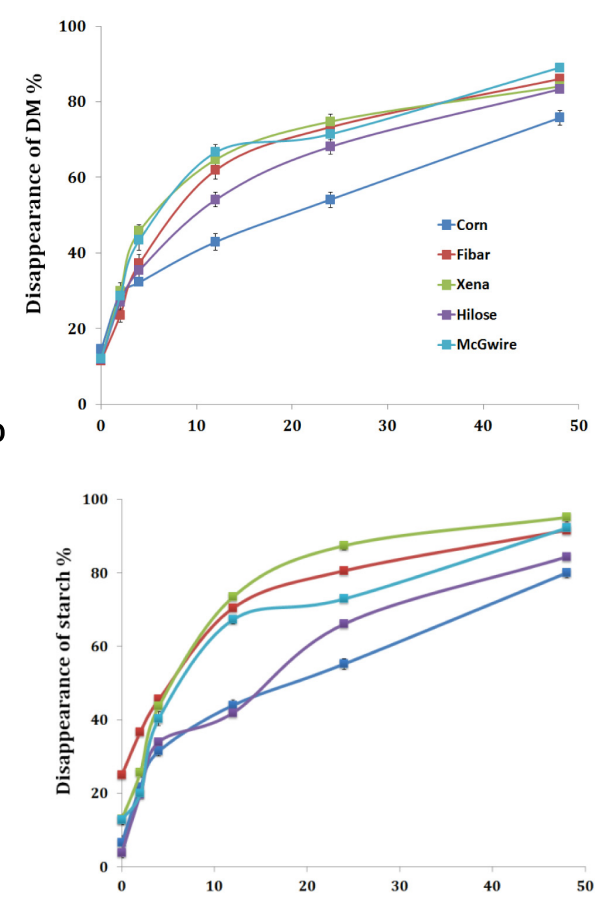

$\mathbf{F}$

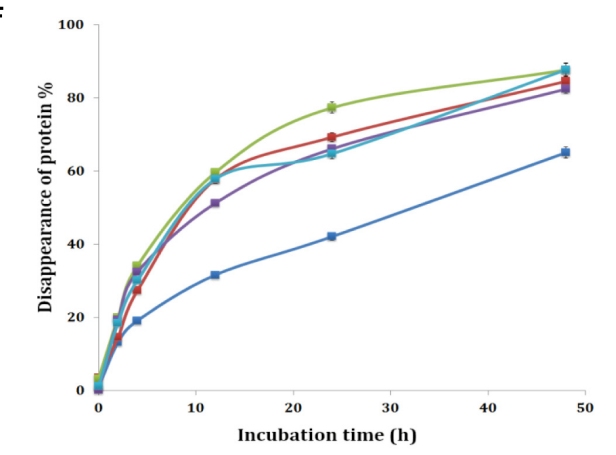

FIGURE 1 | In situ percent DM (A,B), starch (C,D), and protein $\mathbf{( E , F ) ~ d i s a p p e a r a n c e ~ a t ~ s i x ~ d i f f e r e n t ~ r u m i n a l ~ i n c u b a t i o n ~ t i m e s ~ w h e n ~ h e i f e r s ~ w e r e ~ f e d ~ a ~ l o w ~ a n d ~ h i g h ~}$ grain diet.

(45.1\%), and McGwire (31.5\%) than after 2 or $4 \mathrm{~h}$ of incubation (Figure 8C). Compared to barley after $2 \mathrm{~h}$ of incubation, corn had higher $(P<0.05)$ unclassified Ruminococcaceae and Fibrobacter than barley grain and after $4 \mathrm{~h}$ of incubation, CF231 was higher $(P<0.05)$ in corn than barley (data not shown).

\section{Bacterial Morphologies Associated With Barley Grain}

After $2 \mathrm{~h}$ of incubation, SEM images showed initial colonization of starch granules by rumen bacteria, but digestive pits on the surface of starch granules were not apparent (arrows, Figures 9A,B). By $4 \mathrm{~h}$, the formation of rich biofilms with visible digestive pits on the surface of starch granules was evident (arrows, Figures 9C,D). After $12 \mathrm{~h}$ of incubation in the rumen, the protein matrix of starch granules was also undergoing invasion by bacteria and penetration of starch granules by starchdigesting bacteria was observed (Figures 9E,F).

\section{DISCUSSION}

\section{In Situ Degradability of Different Barley Varieties in Heifers Fed Low or High Grain Diets}

Formation of microbial biofilms is a perquisite for efficient ruminal feed digestion (McAllister et al., 1994) as adherent bacteria have been estimated to be responsible for $80 \%$ of the endoglucanase activity, $70 \%$ of the amylase activity 
A
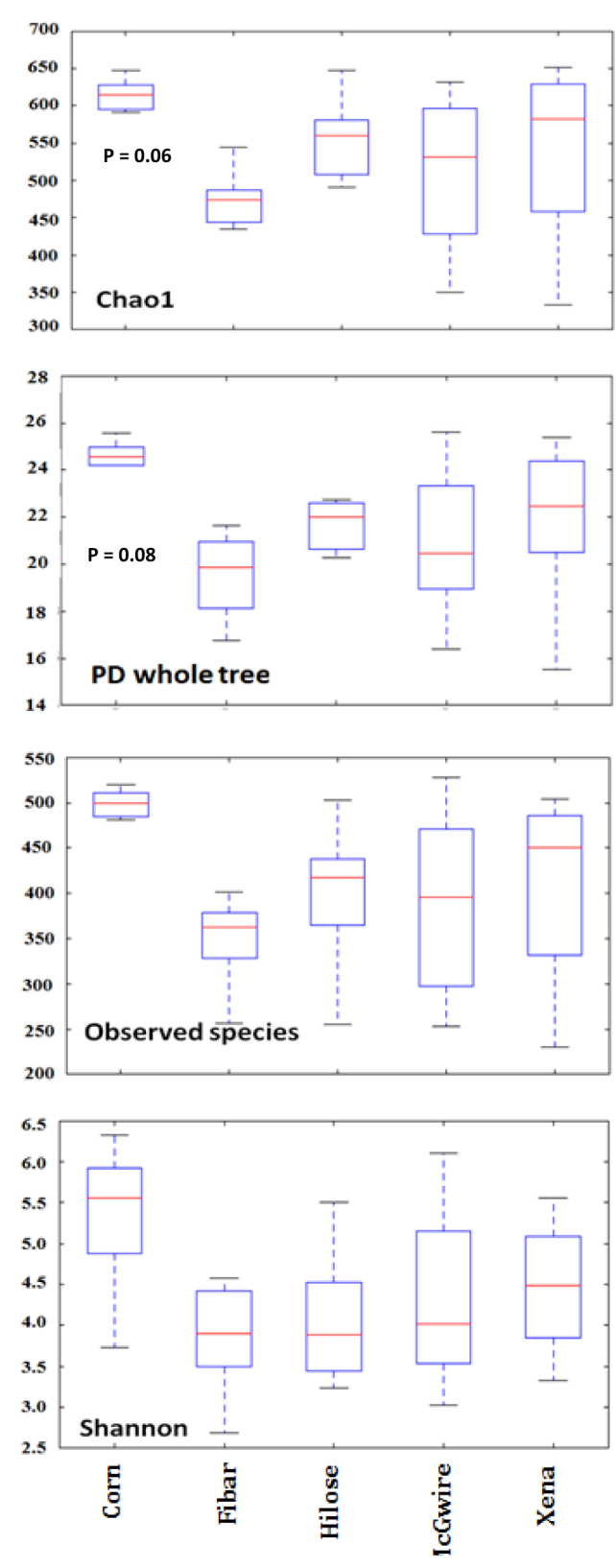

B Heifers fed a high grain diet
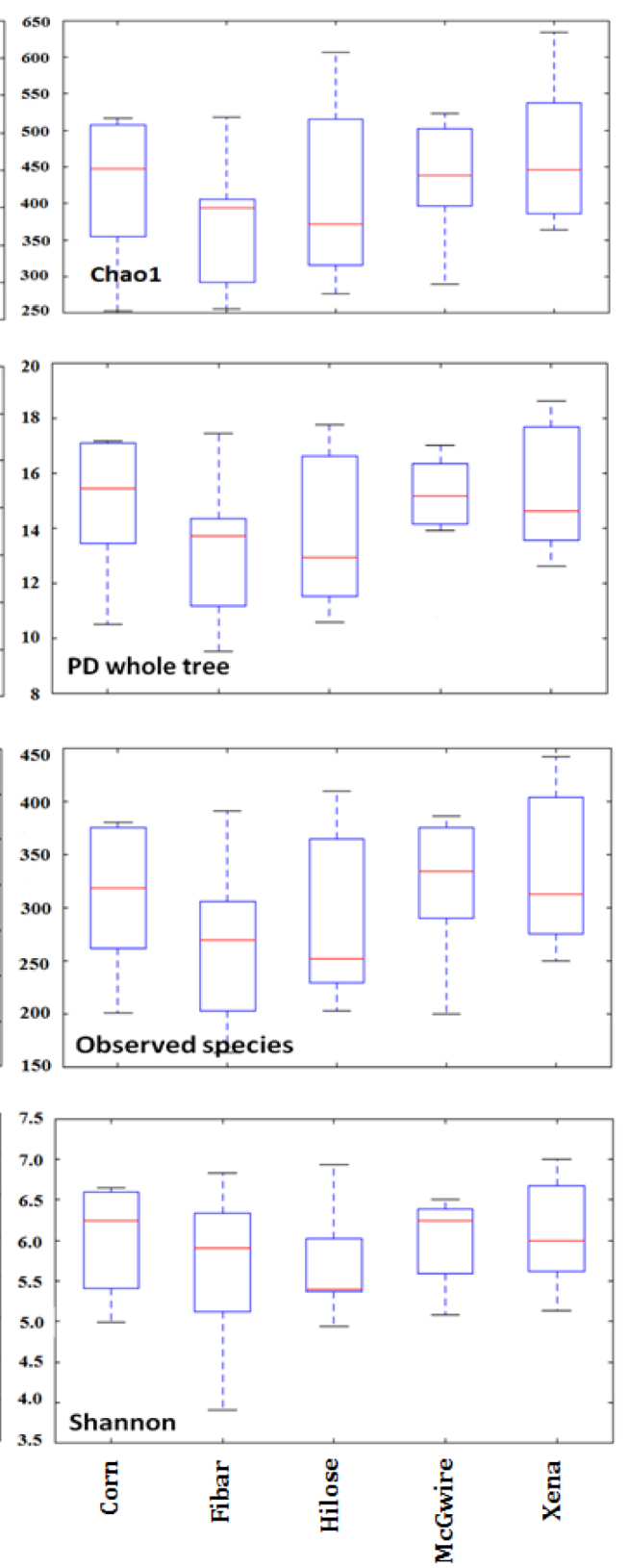

FIGURE 2 | Alpha diversity measures of Chao1, observed species, PD whole tree, and Shannon diversity index associated with biofilms on the surface of corn $(n=6)$ and barley $(n=6)$ incubated in the rumen of heifers fed a low $(\mathbf{A})$ or high grain $(\mathbf{B})$ diet.

(Minato et al., 1966), and 75\% of the protease activity (Brock et al., 1982) in the rumen.

Our in situ degradability study showed that the normal barley varieties of McGwire and Xena, which generally contain an amylose:amylopectin ratio of 1:3, exhibited a higher DM digestibility as compared to high amylose (Hilose) and high amylopectin (Fibar) barley or corn (Table 3). Similarly, Stevnebø et al. (2009) showed that low amylose barley varieties had a greater effective $\mathrm{Kd}(0.148 / \mathrm{h})$ compared to normal amylose
$(0.115 / \mathrm{h})$ and high amylose $(0.102 / \mathrm{h})$ varieties. However, studies comparing the impact of the amylose/amylopectin ratio on starch digestibility in the rumen are limited and inconsistent. Philippeau and Michalet-Doreau (1997) concluded that ruminal starch degradability was not related to amylose content in corn starch, as measured by the in situ bag technique. Interestingly, in our study, corn had lower in situ rumen degradability in both diets as compared to barley. According to McAllister et al. (1993), differences in ruminal starch digestibility 
A

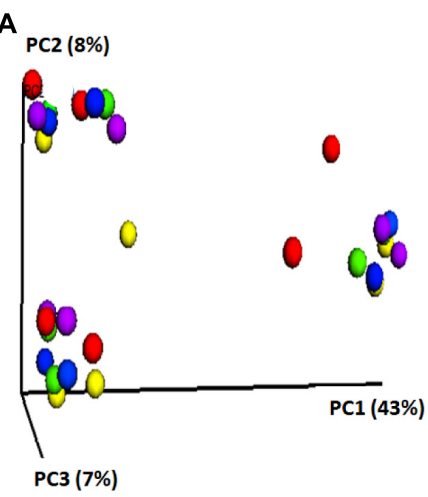

Corn Fibar Hilose

McGiwre Xena
B

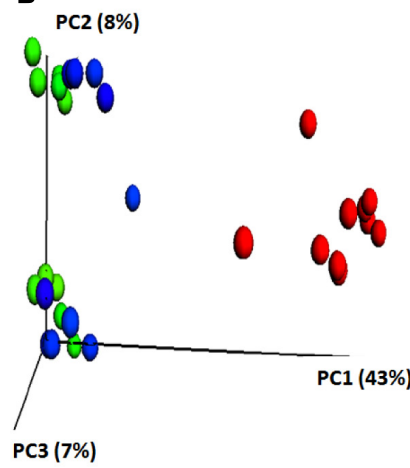

$2 h$

$4 h$

$12 \mathrm{~h}$

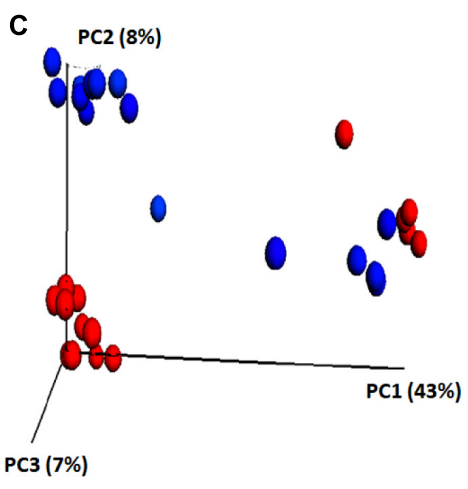

Cow 1

Cow 2

FIGURE 3 | Principle coordinate analysis (PCoA) plots of the unweighted UniFrac distances for biofilm associated bacteria on corn and four barley grain varieties in heifers fed a low grain diet $\mathbf{( A )}$ corn and four barley varieties, (B) sampling time and (C) heifer.

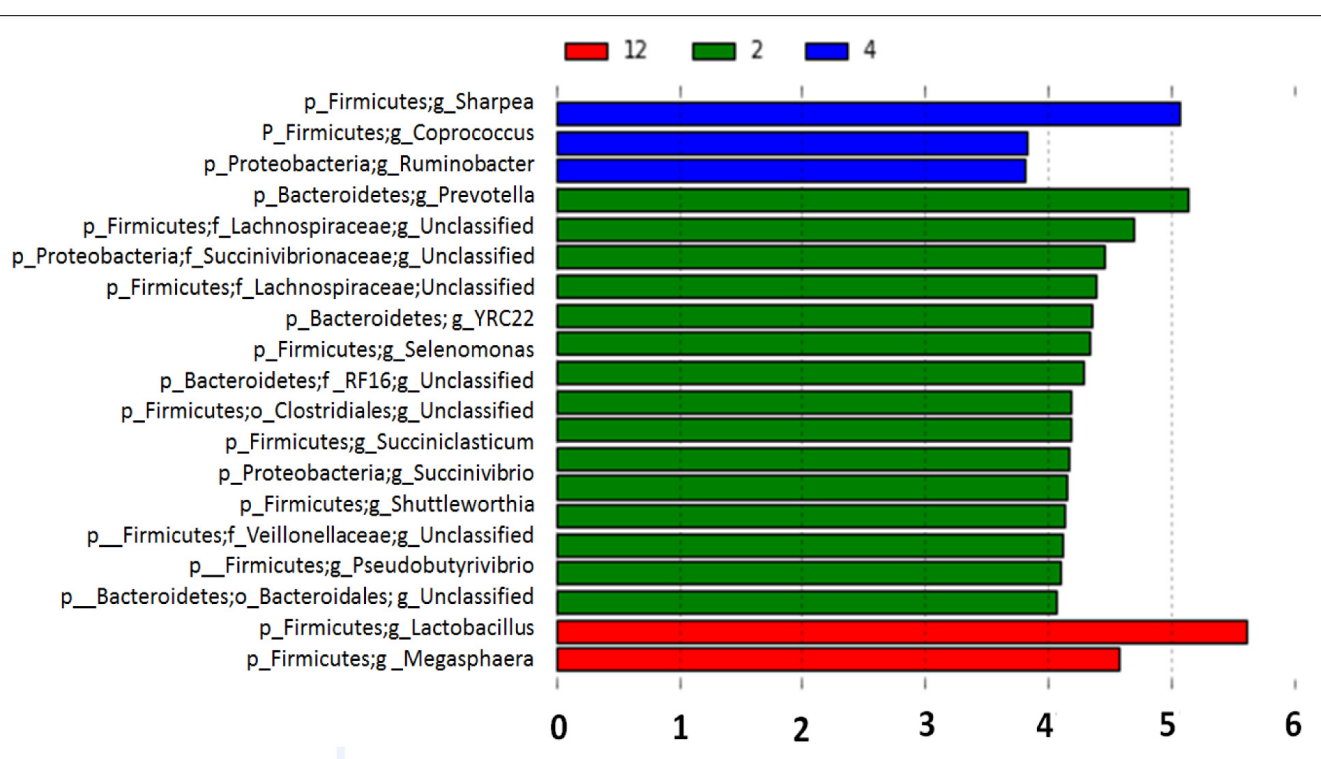

LDA SCORE $(\log 10)$

FIGURE 4 | Differentially abundant genera associated with barley grain after 2, 4, and $12 \mathrm{~h}$ incubation in the rumen of heifers fed a low grain diet from LEfSe analysis. With a log LDA score above 2.00. Lower case letter before taxonomy indicates phylum (p_), family (f_), or genus (g_).

between corn and barley grain are related to differences in the composition and structure of the endosperm rather than starch granules. Moreover, other studies showed that the reduced digestibility of starch in corn was attributable to the protein matrix surrounding starch granules (Weurding et al., 2001). In corn, starch granules may be so tightly associated with the protein matrix (Philippeau et al., 2000; McAllister and Riberio, 2013), that starch resists degradation by rumen bacteria (McAllister et al., 1993; Philippeau et al., 2000), accounting for the lower rate of starch digestion in corn as compared to barley.
Even though our study observed differences in the degradability of barley varieties in both diets, we did not identify clear differences in the biofilm bacterial communities associated with different barley varieties in heifers fed either low or high barley grain diets. This suggests that the variation in degradability among barley varieties was a result of differences in the chemical composition of the grains, and not the bacterial composition of the biofilms partaking in fermentation. However, our study showed changes in the microbiota over time (i.e., 2, 4, and $12 \mathrm{~h}$ of incubation) in all grains, regardless of diet. Interestingly, biofilms exhibited 


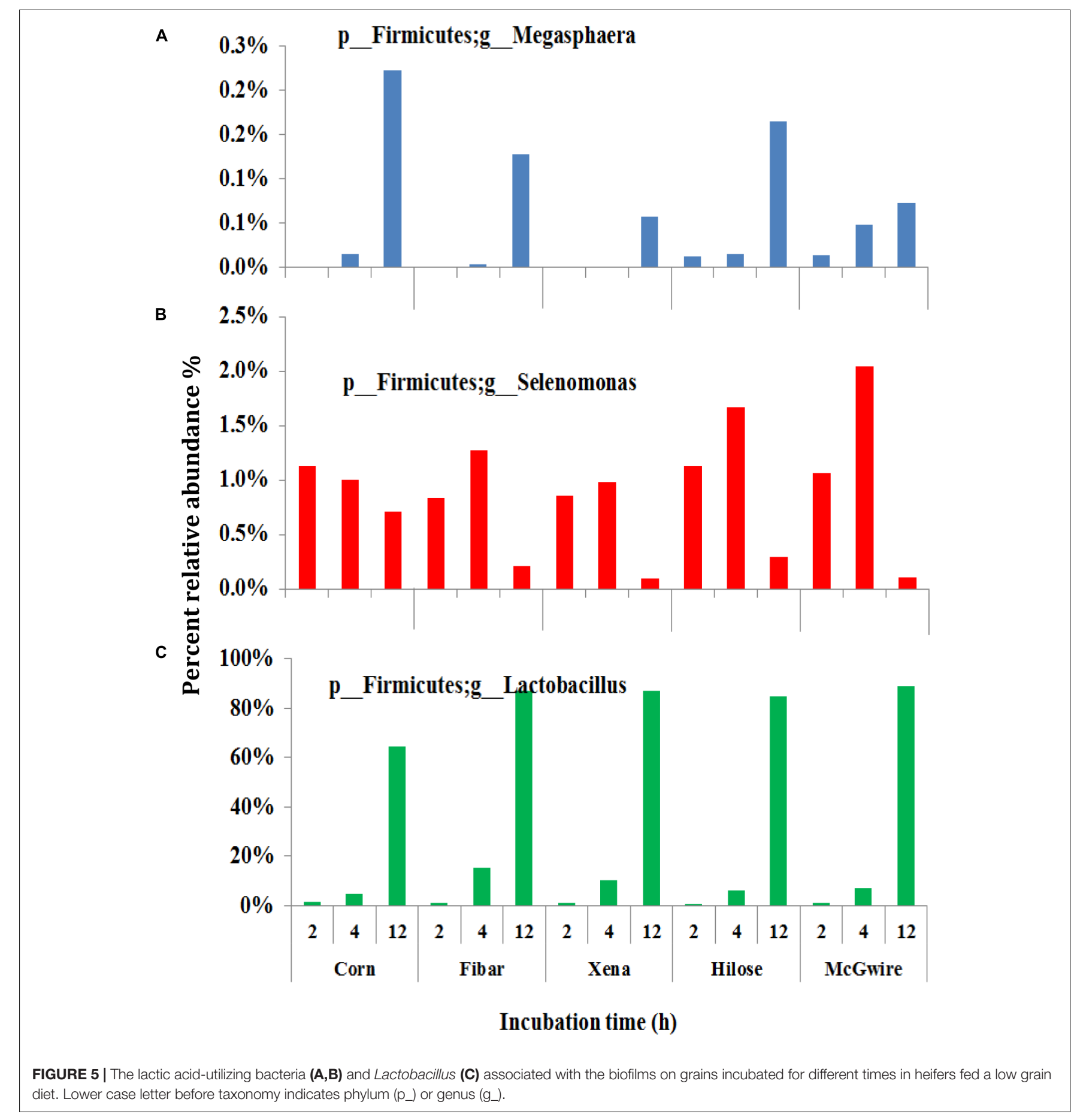

different bacterial diversity between corn and barley irrespective of time and diet. This is probably a result of structural differences in the protein matrix of the grain (i.e., corn versus barley) affecting surface biofilm development rather than differences in starch composition (i.e., among barley varieties). However, the bacterial communities were higher in bacterial diversity and complexity in heifers fed high forage than in those fed high grain. Generally, biofilms are formed by dominant bacteria and evolve with incubation time, possibly in relation to changes in the composition of the feed as digestion proceeds.

\section{Temporal Microbial Colonization of Corn and Barley Grain Within the Rumen}

The biofilms responsible for digestion of feed particles develop overtime, with three successive populations contributing to the biofilm (McAllister et al., 1994; Huws et al., 2016). The first population consists of those loosely associated bacteria that 


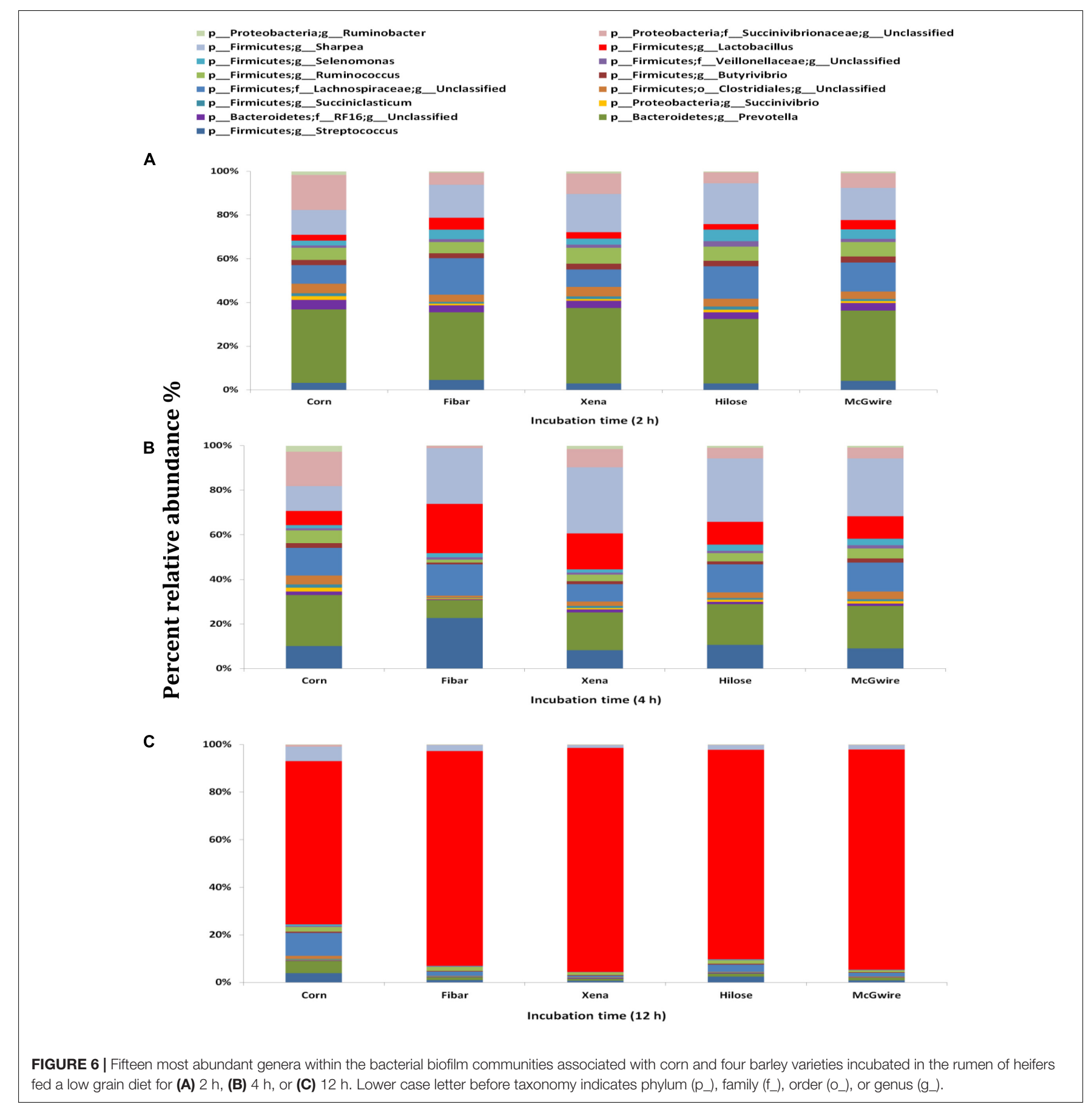

utilize water-soluble sugars and proteins that are available in the early stages of digestion. This population is followed by more tightly associated populations that adhere to the surface of plant cell walls and starch granules, contributing to the establishment of a stable biofilm. Finally, a third population integrates into the biofilm, utilizing the fermentation end products produced by the tightly associated population. Huws et al. (2013) showed that the primary colonizing bacteria were associated with fresh perennial rye grass within $1-2 \mathrm{~h}$ after its introduction into the rumen. Secondary colonizers were shown to join the biofilm of fresh perennial ryegrass within $4-8 \mathrm{~h}$. Interestingly, using denaturing gradient gel electrophoresis, rumen biofilms associated with Chinese wild rye were shown to continue to evolve even after 6 and $12 \mathrm{~h}$ of incubation in the rumen (Sun et al., 2008). These studies support our microscopy data (Figure 9), which showed that at $2 \mathrm{~h}$ incubation, bacteria initiated colonization of starch granules, but mature biofilms had not formed and bacterial invasion of starch granules and the protein matrix had not yet occurred. At $4 \mathrm{~h}$ of incubation, bacterial penetration of starch granules 
A

P_Proteobacteria;f_Succinivibrionaceae;g_Unclassified
P_Proteobacteria;g_Ruminobacter P_Firmicutes;f_Ruminococcaceae;g_Unclassified

\section{2 h of incubation}

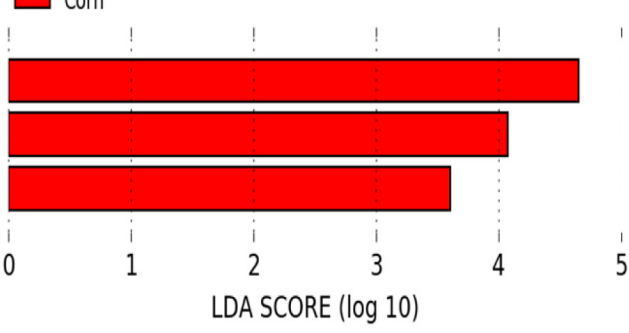

B

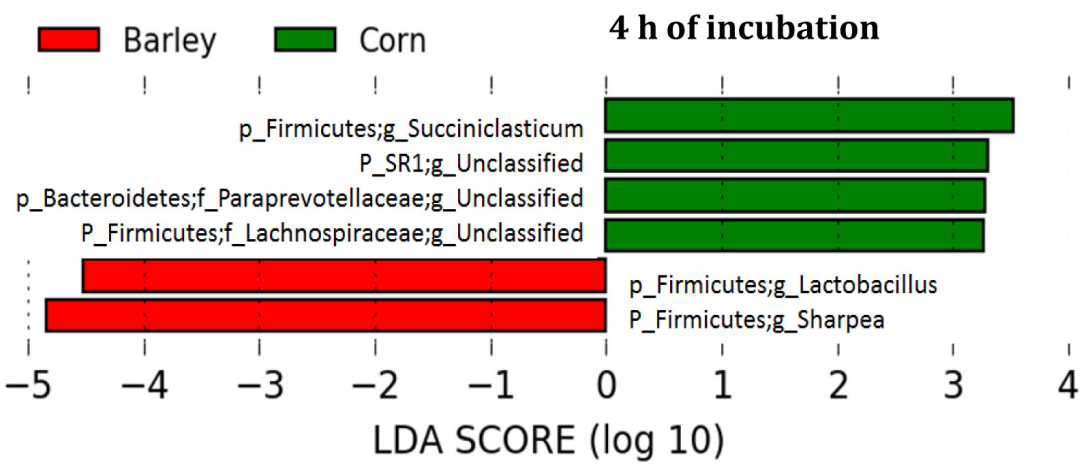

C

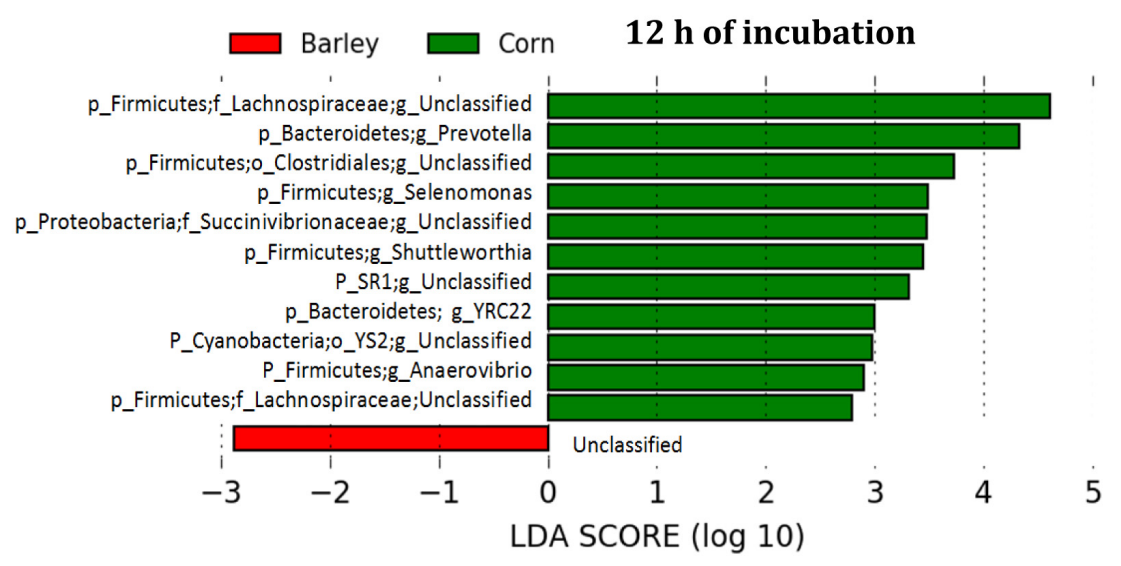

FIGURE 7 | Comparison of corn and barley grain associated biofilms illustrating an increase in the abundance select genera after (A) $2 \mathrm{~h}$, (B) $4 \mathrm{~h}$, and (C) $12 \mathrm{~h}$ of incubation in the rumen of heifers fed a low grain diet. LEfSe analysis used a log LDA score above 2.00. Lower case letter before taxonomy indicates phylum (p_), family (f_), order (o_), or genus (g_).

was apparent, and rich biofilms were visible on the surface of both starch granules and the protein matrix after $12 \mathrm{~h}$ of incubation.

\section{Temporal Microbial Colonization Among Corn and the Four Barley Varieties in Heifers Fed Low Grain Diet}

Even though the bacterial communities in biofilms associated with the four barley varieties did not differ, the bacterial composition of the biofilms did dramatically change over time (Figure 4). The diversity of the primary colonizers was greater than that observed as the biofilm advanced toward maturity. This may reflect the rich variety of soluble and insoluble nutrients available for digestion during the early stages of biofilm formation. As digestion proceeds, soluble nutrients are exhausted and the biofilm becomes more mature and less compositionally diverse (Watnick and Koltr, 2000). Similarly, Huws et al. (2016) found a higher bacterial diversity associated with fresh perennial ryegrass after $1-2 \mathrm{~h}$ of incubation in the rumen as compared 


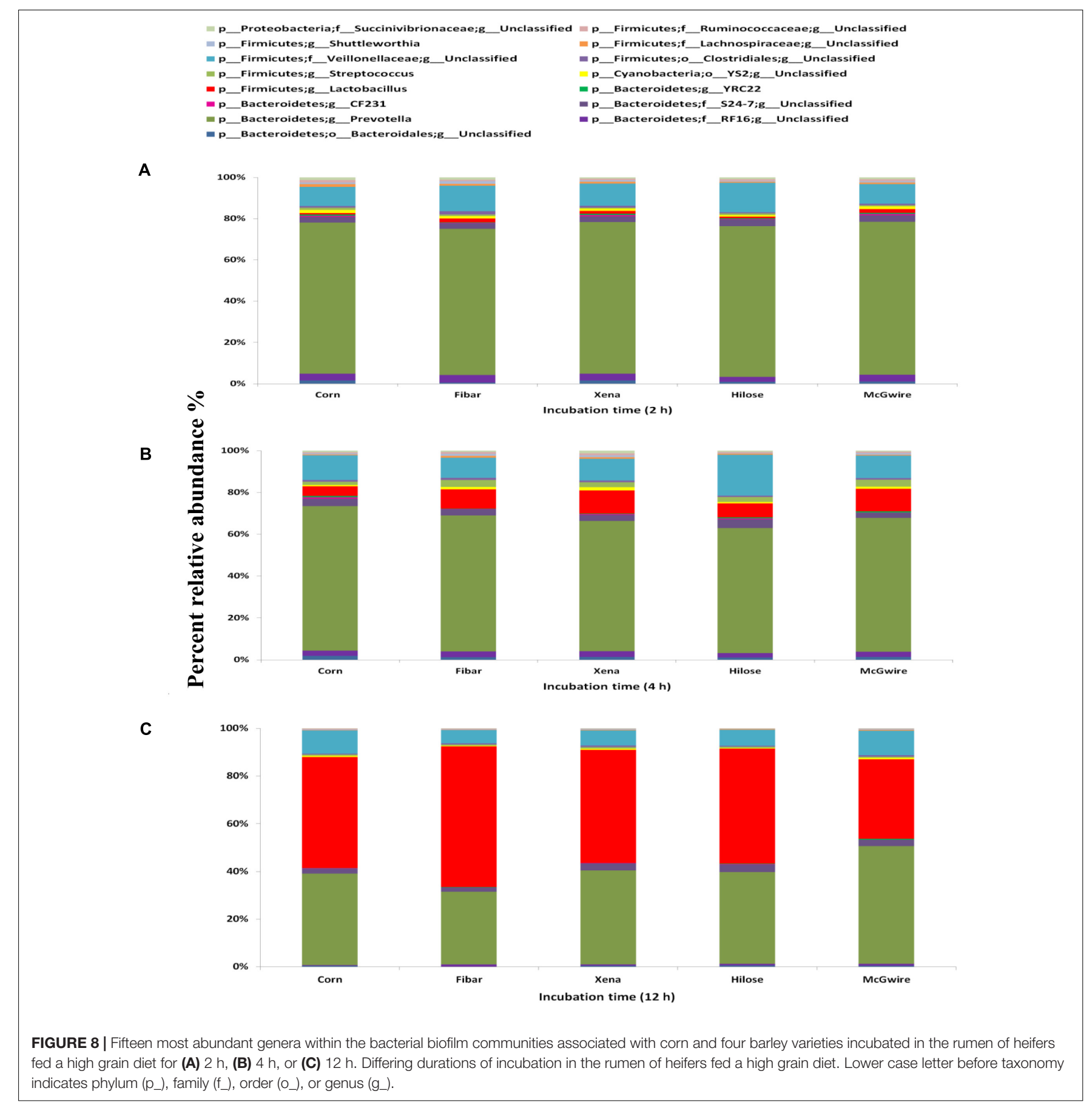

to $4-6 \mathrm{~h}$ of incubation. Compared to barley, primary biofilm formation in corn had higher unclassified Succinivibrionaceae, Ruminobacter, and unclassified Ruminococcaceae, a response that may reflect the higher level of starch in corn. Huws et al. (2016) proposed that primary colonizing bacteria associate first with soluble nutrients, with secondary colonizers being more adept at digesting starch and plant cell walls. During secondary colonization of barley grain, Sharpea, Coprococcus, and Ruminobacter increased, all of which have been associated with starch digestion. As soluble carbohydrates are utilized, the digestion of starch likely intensifies. Digestion is likely enhanced as primary colonizers degrade physical barriers and increase the access of secondary colonizers to starch. Comparison of the secondary colonizers found that four genera (Succiniclasticum, unclassified SR1, unclassified Paraprevotellaceae, and unclassified Lachnospiraceae) were more abundant in biofilms associated with corn than barley. Whereas at this same time, Lactobacillus, and Sharpea were more abundant in biofilms associated with barley than corn. The probable explanation is that corn and barley grain differ in starch structure in relation to 


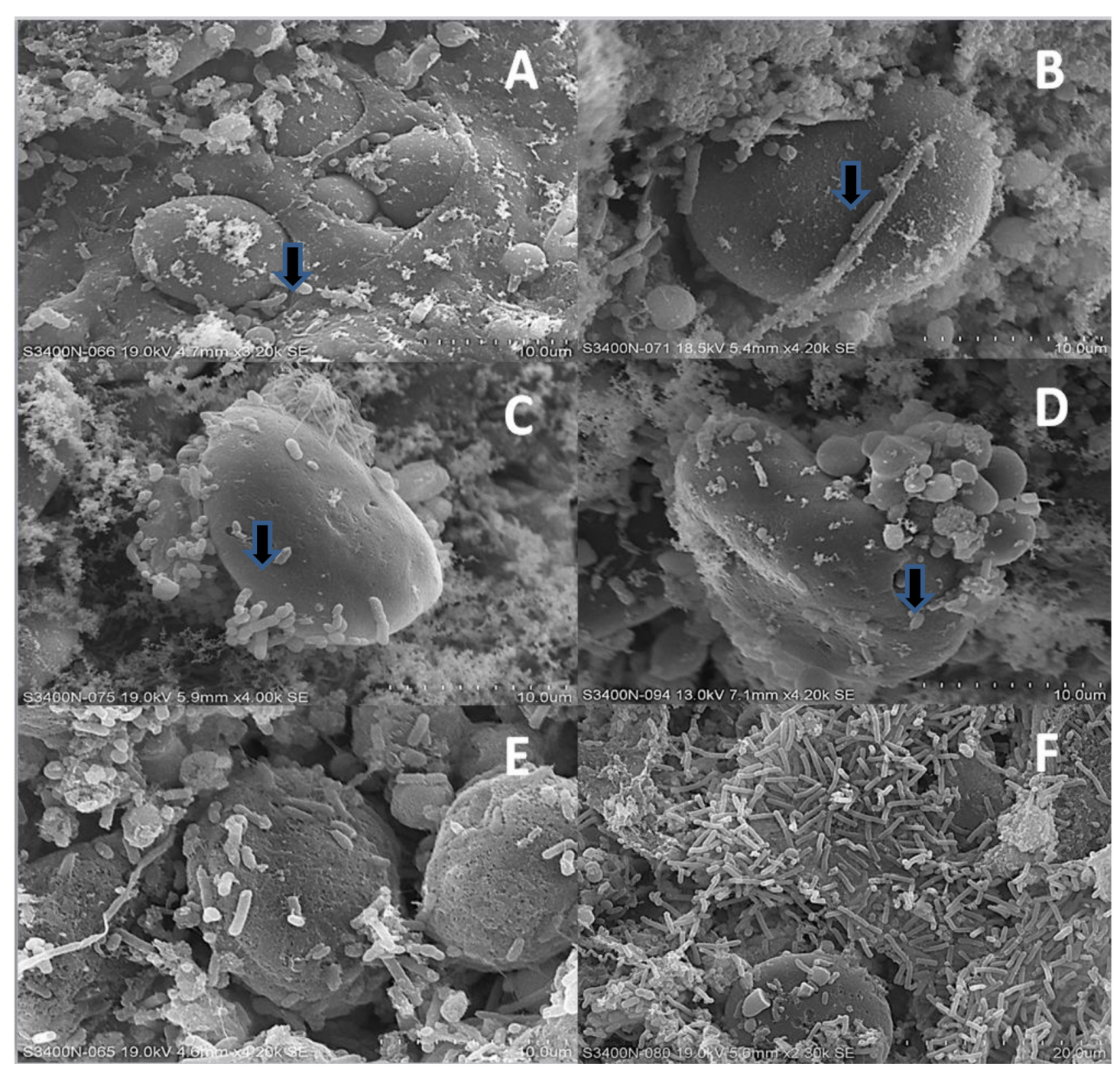

FIGURE 9 | Rumen bacterial biofilms on the surface of grains as viewed using scanning electron microscopy (SEM) after 2, 4, and $12 \mathrm{~h}$ of ruminal incubation. (A) Fibar at 2 h. (B) McGwire at 2 h. (C) Fibar at 4 h. (D) McGwire at 4 h. (E) Fibar at 12 h. (F) McGwire at 12 h.

interaction with the protein matrix. The starch endosperm of corn is tightly associated with the protein matrix, which resists degradation by ruminal bacteria (Philippeau et al., 2000). Whereas, the starch of barley grain is loosely associated with the protein matrix, easily exposed and digested by ruminal bacteria.

In general, tertiary biofilms became less diverse with increasing time in the rumen. This study showed that Lactobacillus and Megasphaera increased in the tertiary biofilm associated with barley grain during primary and secondary colonization (Figure 4). Generally, Lactobacillus is most often associated with ruminal acidosis (Sato, 2016) due to its capacity to rapidly produce large amounts of lactic acid (Hernandez et al., 2007). However, surprisingly, we observed that Lactobacillus increased and accounted for a significant proportion of the adherent microbiota of grains, even when heifers were fed low grain diets. We also found that lactic acid-utilizing Megasphaera increased within the tertiary biofilm. Megasphaera play an important role in preventing the accumulation of lactic acid in the rumen (Castillo-González et al., 2014). Thus, the increase in lactic acid production by Lactobacillus is likely offset by an increase in lactic acid utilization by Megasphaera. This suggests that Lactobacillus is active in starch digestion, even when acidosis is not evident. Counotte et al. (1981) also suggested that Megasphaera elsdenii is the main species responsible for lactic acid metabolism and has an important role in the prevention of lactic acidosis.

Unclassified Lachnospiraceae, Prevotella, unclassified Clostridiales, unclassified Succinivibrionaceae, Shuttleworthia, unclassified SR1, YRC22, unclassified YS2, and Anaerovibrio were more dominant in tertiary biofilms associated with corn than with barley (Figure 7C). This suggests that the nature of the protein matrix or other chemical constituents such as lipid may result in greater bacterial diversity in mature biofilms 
in corn than in barley. This possibility is also supported by the fact that, Prevotella was higher in corn than barley as the superior proteolytic capacity of this bacterium has been well documented (Wallace et al., 1995, 1997). The reason for the increased abundance of unclassified Clostridiales during the tertiary biofilm in corn is unclear, but these genera could also be associated with the digestion of protein matrix in corn. Poppi and Quigley (2003) also found an abundance of unclassified Clostridiales associated with the higher protein levels in a cottonseed meal supplement. The identification of Anaerovibrio a lipolytic bacterium in corn biofilms may also be related to the higher lipid content of this grain.

\section{Temporal Microbial Colonization Among Corn and the Four Barley Varieties in Heifers Fed High Grain Diet}

Biofilm bacterial communities associated with corn and barley grain were also influenced by the level of grain that was fed to heifers. The three genera that were higher during the initial colonization of barley grain included Prevotella, unclassified Succinivibrionaceae, and unclassified Ruminococcaceae. Interestingly, our data showed that Prevotella was the most dominant genus in both grain types (i.e., corn vs. barley grain) and diets (i.e., high fiber and high grain diets) during the initiation of biofilm formation. This is probably because of the diversity of species within Prevotella and the wide range of metabolic functions they possess. Koike et al. (2003) also showed that Prevotella were found to be predominant in the total $16 \mathrm{~S}$ rRNA sequences retrieved from the particle-associated rumen bacterial communities. It has also been shown that members of this genus participate in both fiber and grain digestion (Bekele et al., 2010) and possess both amylolytic and proteolytic activities (Accetto and Avguštin, 2015; Kishi et al., 2015). As with the low grain diet, lactobacilli were also a predominant member of the mature biofilm colonizing grains in heifers fed the high grain diet.

\section{CONCLUSION}

Our study showed that standard barley varieties exhibited higher ruminal DM, starch, and protein digestibility than

\section{REFERENCES}

Accetto, T., and Avguštin, G. (2015). Polysaccharide utilization locus and CAZYme genome repertoires reveal diverse ecological adaptation of Prevotella species. Syst. Appl. Microbiol. 38, 453-461. doi: 10.1016/j.syapm.2015. 07.007

Åman, P., and Newman, C. W. (1986). Chemical composition of some different types of barley grown in Montana, USA. J. Cereal Sci. 4, 133-141. doi: 10.1016/ S0733-5210(86)80016-9

AOAC (1997). Official Methods of Analysis of the Association of Official Analytical Chemists, 20th Edn. Washington DC: Association of Official Analytical Chemists.

AOAC (2010). Official Methods of Analysis of Official Analytical Chemists, 18th Edn. Arlington, VA: Association of Official Analytical Chemists. high amylose and amylopectin varieties. However, these differences in digestion were not reflected in the composition of the biofilm communities responsible for the digestion of these grains. Prevotella were the predominant primary colonizers of grains in heifers fed either low or high grain diets. Starch digestion was accelerated upon establishment of the secondary colonizers with Lactobacillus predominating in mature biofilms that were less diverse than during initial colonization. The inclusion of lactic acid utilizing bacteria within mature biofilms likely plays a significant role in preventing the accumulation of lactic acid in the rumen.

\section{AUTHOR CONTRIBUTIONS}

HY, JM, and TM designed the study and wrote the manuscript. $\mathrm{HY}$ and $\mathrm{CZ}$ carried out the experimental procedures and analysis. HY and TM conducted the statistical and bioinformatics analysis. TM provided funding. All the authors reviewed and approved the final manuscript.

\section{FUNDING}

This study was conducted with funding from Barley Research Cluster of Agriculture and Agri-Food Canada and the Alberta Crop Industry Development Fund.

\section{ACKNOWLEDGMENTS}

We thank Wendi Smart and animal handling staff for their technical assistance.

\section{SUPPLEMENTARY MATERIAL}

The Supplementary Material for this article can be found online at: https://www.frontiersin.org/articles/10.3389/fmicb. 2018.00718/full\#supplementary-material

Beauchemin, K. A., Yang, W. Z., and Rode, L. M. (2001). Effects of barley grain processing on the site and extent of digestion of beef feedlot finishing diets. J. Anim. Sci. 79, 1925-1936. doi: 10.2527/2001.797 $1925 x$

Bekele, Z. A., Koike, S., and Kobayashi, Y. (2010). Genetic diversity and diet specificity of ruminal Prevotella revealed by $16 \mathrm{~S}$ rRNA gene-based analysis. FEMS Microbiol. Lett. 305, 49-57. doi: 10.1111/j.1574-6968.2010.01911

Brock, F. M., Forsberg, C. W., and Buchanan-Smith, J. G. (1982). Proteolytic activity of rumen microorganisms and effects of proteinase inhibitors. Appl. Environ. Microbiol. 44, 561-569.

Canadian Council on Animal Care [CCAC] (2009). Guidelines on: The Care, and use of Farm Animals in Research (Teaching ) and Testing. Paris: CCAC.

Caporaso, J. G., Kuczynski, J., Stombaugh, J., Bittinger, K., Bushman, F. D., Costello, E. K., et al. (2010). QIIME allows analysis of high-throughput 
community sequencing data. Nat. Methods 7, 335-336. doi: 10.1038/nmeth. f.303

Castillo-González, A. R., Burrola-Barraza, M. E., Domínguez-Viveros, J., and Chávez- Martínez, A. (2014). Rumen microorganisms and fermentation. Arch. Med. Vet. 46, 349-361. doi: 10.4067/S0301-732X201400030 0003

Chao, A. (1984). Nonparametric estimation of the number of classes in a population. Scand. J. Stat. 11, 265-270.

Cleary, L. J., Van Herk, F., Gibb, D. J., McAllister, T. A., and Chaves, A. V. (2011). Dry matter digestion kinetics of two varieties of barley grain sown with different seeding and nitrogen fertilization rates in four different sites across Canada. Asian Aust. J. Anim. Sci. 7, 965-973. doi: 10.5713/ajas.2011. 10427

Corn Refiners Association (1997). Corn Refiners Association Standard Analytical Methods. Washington, DC: CRA.

Counotte, G. H. M., Prins, R. A., Janssen, R. H. A. M., and deBie, M. J. A. (1981). Role of Megasphaera elsdenii in the fermentation of $\mathrm{dl}-\left[2-{ }^{13} \mathrm{C}\right]$ lactate in the rumen of dairy cattle. Appl. Environ. Microbiol. 42, 649-655.

Dowd, S. E., Callaway, T. R., Wolcott, R. D., Sun, Y., McKeehan, T., Hagevoort, R. G., et al. (2008). Evaluation of the bacterial diversity in the feces of cattle using 16S rDNA bacterial tag-encoded FLX amplicon pyrosequencing (bTEFAP). BMC Microbiol. 8:125. doi: 10.1186/1471-2180-8-125

Edgar, R. C. (2010). Search and clustering orders of magnitude faster than BLAST. Bioinformatics 26, 2460-2461. doi: 10.1093/bioinformatics/btq461

Faith, D. P. (1992). Conservation evaluation and phylogenetic diversity. Biol. Conserv. 61, 1-10. doi: 10.1016/0006-3207(92)91201-3

Good, I. J. (1953). On population frequencies of species and the estimation of population parameters. Biometrika 40, 237-264. doi: 10.1093/biomet/40. 3-4.237

Hernandez, J. D., Shephard, R. W., and Al Jassim, R. A. M. (2007). The characterization of lactic acid producing bacteria from the rumen of dairy cattle grazing on improved pasture supplemented with wheat and barley grain. J. Anim. Sci. 104, 1754-1763. doi: 10.1111/j.1365-2672.2007. 03696.x

Herrera-Saldana, R. E., Huber, L. T., and Poore, M. H. (1990). Dry matter, crude protein, and starch degradability of five cereal grains. J. Dairy Sci. 73, 2386-2393. doi: 10.3168/jds.S0022-0302(90)78922-9

Huws, S. A., Edwards, J. E., Creevey, C. J., Rees Stevens, P., Lin, W., and Girdwood, S. E. (2016). Temporal dynamics of the metabolically active rumen bacteria colonising fresh perennial ryegrass. FEMS Microbiol. Ecol. 7:1854. doi: 10.3389/ fmicb.2016.01854

Huws, S. A., Mayorga, O. L., Theodorou, M. K., Kim, E. J., Newbold, C. J., and Kingston-Smith, A. H. (2013). Successional colonization of perennial ryegrass by rumen bacteria. Lett. Appl. Microbiol. 56, 186-196. doi: 10.1111/lam. 12033

Kishi, L. T., de Jesus, R. B., Pavani, C. D., Lemos, E. G., and de Souza, J. A. (2015). Metagenomic assembly and draft genome sequence of an uncharacterized Prevotella sp. from Nelore rumen. Genome Announc. 3:e00723-15. doi: 10.1128/ genomeA.00723-15

Koike, S., Yoshitani, S., Kobayashi, Y., and Tanaka, K. (2003). Phylogenetic analysis of fiber-associated rumen bacterial community and PCR detection of uncultured bacteria. FEMS Microbiol. Lett. 229, 23-30. doi: 10.1016/S03781097(03)00760-2

Kong, D., Choo, T. M., Jui, P., Ferguson, T., Therrien, M. C., Ho, M., et al. (1995). Variation in starch, protein, and fibre of Canadian barley cultivars. Can. J. Plant Sci. 75, 865-870. doi: 10.4141/cjps95-143

Lozupone, C., and Knight, R. (2005). UniFrac: a new phylogenetic method for comparing microbial communities. Appl. Environ. Microbiol. 71, 8228-8235. doi: 10.1128/AEM.71.12.8228-8235.2005

McAllister, T., Phillippe, R., Rode, L., and Cheng, K. (1993). Effect of the protein matrix on the digestion of cereal grains by ruminal microorganisms. J. Anim. Sci. 71, 205-213. doi: 10.2527/1993.711205x

McAllister, T. A., Bae, H. D., Jones, G. A., and Cheng, K.-J. (1994). Microbial attachment and feed digestion in the rumen. J. Anim. Sci. 72, 3004-3018. doi: $10.2527 / 1994.72113004 \mathrm{x}$

McAllister, T. A., and Riberio, G. J. (2013). "Microbial strategies in the digestion of starch in the rumen," in Proceedings of the 50th Annual Meeting of the Brazilian Society of Animal Science, Campinas, 140-151.
McDonald, I. (1981). A revised model for the estimation of protein degradability in the rumen. J. Agric. Sci. 96, 251-252. doi: 10.1017/S00218596000 32081

Minato, H., Endo, A., Ootome, Y., and Uemura, T. (1966). Ecological treatise on the rumen fermentation. II. The amylolytic and cellulolytic activities of fractionated bacterial portions attached to the rumen solids. J. Gen. Appl. Microbiol. 12, 53-61. doi: 10.2323/jgam.12.53

Narasimhalu, P., Kong, D., Choo, T. M., Ferguson, T., Therrien, M. C., Ho, K. M., et al. (1995). Effects of environment and cultivar on total mixed-linkage $\beta$-glucan content in eastern and western Canadian barleys (Hordeum vulgare L.). Can. J. Plant Sci. 75, 371-376. doi: 10.4141/cjps 95-062

Nikkhah, A. (2012). Barley grain for ruminants: a global treasure or tragedy. J. Anim. Sci. Biotechnol. 3:22. doi: 10.1186/2049-1891-3-22

Nilan, R. A., and Ullrich, S. E. (1993). "Barley: taxonomy, origin, distribution, production, genetics, and breeding," in Barley Chemistry and Technology, eds A. W. MacGregor and R. S. Bhatty (St. Paul, MN: American Association of Cereal Chemists), 1-29.

Ørskov, E. R., and McDonald, I. (1979). The estimation of protein degradability in the rumen from incubation measurements weighed according to rate of passage. J. Agric. Sci. 92, 499-503. doi: 10.1017/S002185960006 3048

Oscarsson, M., Andersson, R., Salomansson, A. C., and Åman, P. (1996). Chemical composition of barley samples focusing on dietary fire components. J. Cereal Sci. 24, 161-169. doi: 10.1006/jcrs.1996.0049

Peter, K., and Herbert, W. (2013). Chapter 2: Chemistry of Cereal Grains. Berlin, NH: Springer.

Petri, R. M., Schwaiger, T., Penner, G. B., Becauchemin, K. A., Forster, R. J., McKinnon, J. J., et al. (2013). Characterization of the core rumen microbiota in cattle during transition from forage to concentrate as well as during and after an acidotic challenge. PLoS One 8:e83424. doi: 10.1371/journal.pone. 0083424

Philippeau, C., Landry, J., and Michalet-Doreau, B. (2000). Influence of protein distribution of maize endosperm on ruminal starch digestibility. J. Sci. Food Agric. 80, 404-408. doi: 10.1002/1097-0010(200002)80:3<404::AID-JSFA541> 3.0.CO;2-Z

Philippeau, C., and Michalet-Doreau, B. (1997). Influence of genotype and stage of maturity of maize on rate of ruminal starch degradation. Anim. Feed Sci. Technol. 68, 25-35. doi: 10.1016/S0377-8401(97)00042-4

Poppi, D. P., and Quigley, S. (2003). Increased Efficiency of Microbial Protein Production in the Rumen through Manipulation of Nutrients and Rumen Microbial Populations. North Sydney: Meat \& Livestock Australia Limited, 2059.

Price, M. N., Dehal, P. S., and Arkin, A. P. (2010). FastTree 2 - Approximate maximum-likelihood trees for large alignments. PLoS One 5:e9490. doi: 10.1371/journal.pone.0009490

Sato, S. (2016). Pathophysiological evaluation of subacute ruminal acidosis (SARA) by continuous ruminal pH monitoring. J. Anim. Sci. 87, 168-177. doi: 10.1111/ asj. 12415

Segata, N., Izard, J., Waldron, L., Gevers, D., Miropolsky, L., Garrett, W. S., et al. (2011). Metagenomic biomarker discovery and explanation. Genome Biol. 12:R60. doi: 10.1186/gb-2011-12-6-r60

Shannon, C. E. (1948). A mathematical theory of communication. Bell Syst. Tech. J. 27, 379-423. doi: 10.1002/j.1538-7305.1948.tb01338.x

Stevnebø, A., Seppala, A., Harstad, O. M., and Huhtanen, P. (2009). Ruminal starch digestion characteristics in vitro of barley cultivars with varying amylose content. Anim. Feed Sci. Technol. 148, 167-182. doi: 10.1016/j.anifeedsci.2008. 03.011

Sun, Y. Z., Mao, S. Y., and Yao, W. (2008). DGGE and 16S rDNA analysis reveals a highly diverse and rapidly colonising bacterial community on different substrates in the rumen of goats. Animal 2, 391-398. doi: 10.1017/ S1751731107001231

Vazquez-Baeza, Y., Pirrung, M., Gonzalez, A., and Knight, R. (2013). EMPeror: a tool for visualizing high-throughput microbial community data. Gigascience 2:16. doi: 10.1186/2047-217X-2-16

Wallace, R. J., Kopecny, J., Broderick, G. A., Walker, N. D., Sichao, L., Newbold, C. J., et al. (1995). Cleavage of di- and tripeptides by Prevotella ruminicola. Anaerobe 1, 335-343. doi: 10.1006/anae.1995.1036 
Wallace, R. J., McKain, N., Broderick, G. A., Rode, L. M., Walker, N. D., Newbold, C. J., et al. (1997). Peptidases of the rumen bacterium Prevotella ruminicola. Anaerobe 3, 35-42. doi: 10.1006/anae.1996. 0065

Watnick, P., and Koltr, R. (2000). Biofilm, city of microbes. 2000. J. Bacteriol. 182, 2675-2679. PMC101960. doi: 10.1128/JB.182.10.2675-2679. 2000

Weurding, R. E., Veldman, A., Veen, W. A., van, der Aar, P. J., and Verstegen, M. W. (2001). Starch digestion rate in the small intestine of broiler chickens differs among feedstuffs. J. Nutr. 131, 2329-2335. doi: 10.1093/jn/131.9. 2329
Conflict of Interest Statement: The authors declare that the research was conducted in the absence of any commercial or financial relationships that could be construed as a potential conflict of interest.

Copyright (๑) 2018 Yang, Zotti, McKinnon and McAllister. This is an open-access article distributed under the terms of the Creative Commons Attribution License (CC BY). The use, distribution or reproduction in other forums is permitted, provided the original author(s) and the copyright owner are credited and that the original publication in this journal is cited, in accordance with accepted academic practice. No use, distribution or reproduction is permitted which does not comply with these terms. 